\title{
MISLEADING APPEARANCES IN THE TORT OF DECEIT
}

\author{
JOHN MURPHY*
}

\begin{abstract}
This article explores certain key features of the tort of deceit which, if looked at only superficially, are apt to mislead as to the gist, nature and province of this tort. In particular, the article addresses three main issues. The first is the way in which the reliance test used in this tort comes apart from a simple (more familiar) test of causation, and why this has important theoretical ramifications. Secondly, the article seeks to reveal the true gist and province of this tort. In this regard, it is argued that it is a mistake - made by many - to suppose that the infliction of economic loss forms the gist of deceit. Instead, it is suggested that the tort is better seen as being rights based, and that consequently, it ought not to be seen as a specifically economic tort, but rather as one which protects the victim's decision-making autonomy. Lastly, the article unearths the juristic explanation for the curious fact that, in the tort of deceit, the operation of the contributory negligence defence is excluded while the mitigation principle is applied openly. (The incoherence here inheres in the fact that both these principles are animated by the self-same concern: a desire to exclude the recovery of losses that are attributable to an unreasonable lack of self-regard on the part of the claimant.) The juristic explanation I unearth is then subjected to critical analysis in the course of which I suggest that we ought not to confuse explanation with justification. I conclude that there is no sound reason of principle to exclude the operation of the contributory negligence defence in this tort.
\end{abstract}

\section{INTRODUCTION}

Deceit is a peculiar tort; but not, despite initial appearances, because some of its key features are highly unusual in modern-day tort law (such as the remoteness test it employs and its ability to be invoked in connection with pure economic loss). Rather, what causes it to be so curious - a paradox, perhaps - is the fact that those of its central features which appear superficially to be entirely quotidian, turn out to be the hardest to explain; while others, which seem ostensibly to be highly unusual, are in fact what render it a much more normal tort than it is apt initially to appear.

This article seeks to expose and explore the various ways in which appearances can be deceptive in the tort of deceit. In so doing, it endeavours to address a complaint I have long since harboured: namely, that detailed academic reflection on the gist, nature and province of this tort is largely conspicuous by its absence. ${ }^{1}$ This complaint is fuelled by the fact that deceit is an important tort in both practical and theoretical terms. From a practical point of view, there is a steady stream

\footnotetext{
* Lancaster University. Correspondence address: School of Law, University of Lancaster, Lancaster LA1 4YW. Email: J.Murphy2@,lancaster.ac.uk. I am grateful to the following for their valuable comments on drafts of this article, or their discussion of arguments made in it: David Campbell, Hazel Carty, William Lucy, Jason Neyers, Steve Smith and Christian Witting. I am also indebted to the two Cambridge Law Journal referees for their helpful remarks.

${ }^{1}$ Most textbooks and treatises on the law of torts eschew analytical rigour in favour of only fairly cursory accounts of this tort. The notable exception is H. Carty, An Analysis of The Economic Torts (Oxford 2010), ch. 9.
} 
of reported cases in which it features prominently. ${ }^{2}$ And from a theoretical perspective, deceit is intimately implicated in the broad question of how best to understand tort law generally, and the somewhat narrower question of how, if at all, the economic torts can be rationalized and theorized.

The overall aim of this study will be to interrogate the paradox adverted to above with a view to evincing, first, a clearer understanding of the nature and domain of this tort than has hitherto been supplied, and, secondly, a better appreciation of how it can best be explained and justified in theoretical terms. More precisely, I will seek to identify clearly the conceptual space it occupies within tort law and to render it intelligible according to what is probably the leading theoretical understanding of tort law these days: rights-based theory. ${ }^{3}$

En route, as already indicated, a number misconceptions - all of which are bound up with the misleading first impressions created by this tort - will be exposed and explored. So, for example, it will be shown that deceit has nothing especially to do with the protection of economic interests despite widely being regarded as one of the economic torts. Rather, it will be argued that deceit is better seen as being concerned with the protection of individual decision-making autonomy. Equally, I shall contend that - although harm must always be shown in this tort - it is a mistake to regard harm (still less, economic harm) as its gist. Taken together these two observations will ground a more theoretical, third claim: namely, that deceit cannot be explained according to a loss-based conception of tort law, but that it is perfectly intelligible according to a rights-based understanding.

In respect of its more innocuous facets, there is also work to be done. In particular, there are two unchallenged aspects of this tort that are hard to reconcile. The first of these is the seemingly uncontroversial fact that the defence of contributory negligence is unavailable in deceit. The second is the apparently non-contentious fact that the mitigation rule does apply in this context. The tension here inheres in the fact that the contributory negligence defence and the mitigation rule are often thought to be essentially the same thing, separated only on a temporal basis. According to many jurists, an injurious, unreasonable lack of self-regard before the tort is committed is contributory negligence, while a similar lack of self-regard after the tort's commission amounts to a

\footnotetext{
${ }^{2}$ In the three years prior to the writing of this article, there were over 20 reported cases revealed by a $W$ estlaw search in which deceit was either relied on as the main, or alternative, cause of action. Furthermore, deceit remains relevant in some cases of causing loss by unlawful means even though the party actually deceived may be a mere unharmed intermediary (as in, e.g. National Phonographic Co. Ltd. v Edison-Bell Consolidated Phonograph Co. Ltd. [1908] 1 Ch. 335).

${ }^{3}$ Although there are important differences between various versions of rights-based theory, none of them are significant for present purposes. The treatment of deceit by some of the leading rights theorists is considered in Section IV of this article.
} 
failure to mitigate. How then, if this is right, can the tort of deceit coherently exclude contributory negligence, but embrace the mitigation principle?

In order for this article to achieve its stated objectives, I need not unpick or explore every element in the tort of deceit. Some of these elements are already well understood having received considerable judicial (as well as limited juristic) attention in the past. For example, one touchstone of liability that has already been elucidated with a high degree of specificity is that of a false representation. The concept of dishonesty is another. Instead, for present purposes, we need only attend to those aspects of the tort which are problematic either because they are apparently odd characteristics for a tort to possess, or because they appear on the surface to be run-of-the-mill, but in fact turn out to be puzzling.

The article unfolds as follows. In section II, I examine the reliance component in deceit which operates in place of the more familiar tort law requirement of (what I will call for convenience) causation simpliciter. ${ }^{4}$ In particular, taking a steer from a study of the equivalent cause of action in the USA, ${ }^{5}$ I shall explain why reliance must be distinguished from causation simpliciter (even though reliance constitutes the specific mechanism through which causation must occur) if we are to understand a matter of particular importance in the English context. This matter of specific importance concerns the way in which deceit in three-party cases - that is, where $A$ deceives $B$ such that $B$ then acts in a way which causes loss to $C$ - inter-relates with the tort of causing loss by unlawful means as set out by the House of Lords in $O B G v$ Allan. ${ }^{6}$ While $O B G$ might plausibly be thought to constitute the most important decision in the law of torts for a decade or more, and

${ }^{4}$ Arguably, it is not very helpful, perhaps even misleading, to set up a contrast between the reliance requirement in deceit and what I have chosen to call causation simpliciter. This is because tort law embraces a number of different conceptions of causation rather than one simple one. These varying conceptions include the well-known "but for", and (more sophisticated) NESS tests as well as a number of other, policy-driven rules that have little to do with genuine cause and effect. Nonetheless, I think that there exists a link between each of these other approaches to causation which is signally absent in the case of deceit. It is this. Virtually all other tests of causation have as their primary point of focus what $D$ did so as to bring about occurrence X. In deceit, however, the primary point of focus is what $C$ did: namely, rely to his detriment upon a false statement made by $D$. It is the fact that primary attention is ordinarily devoted to $D$ 's acts (rather than to $C$ s acts in combination with, or subsequent to, $D$ 's acts) that is intended to be captured by my use of the term "causation simpliciter". Admittedly, Cs bypothetical conduct might occasionally play a part in the causation enquiry outside the province of deceit (see, e.g. McWilliams v Arrol [1962] 1 W.L.R. 295), but even here Cs hypothetical conduct can be distinguished from $C$ s actual conduct (which is central to the reliance question in deceit).

For a thoroughgoing, reductive account of the various tests for causation in the law of torts in which the unifying thread is identified as being the "defendant's involvement" in the occurrence of a particular phenomenon, see J. Stapleton, "Choosing What We Mean by Causation in the Law" (2008) 73 Missouri L. Rev. 433, 474.

5 In the USA the action is generally labelled "fraud", although the term "deceit" can be used as a synonym. In English law, fraud is not an appropriate synonym due to the existence of a sui generis form of action which has been judicially labelled "fraud" and which involves the bribing of agents so as to extract money from their principals. And this action "based on bribery is not a species of deceit ... [since] there is no representation made to the principal of the agent, let alone reliance": Petrotrade Inc. $v$ Smith [2000] 1 Lloyd's Rep. 486, 490 per Steel J.

${ }^{6}$ [2008] UKHL 19; [2008] 1 A.C. 1. 
while it unquestionably answered a number of pressing questions concerning the economic torts, it nonetheless raised a good many other questions, ${ }^{7}$ of which the nature of the inter-relationship between deceit and the unlawful means tort is but one. In what follows, I shall contend that a proper grasp of the role of reliance in deceit is vital to understanding the deceit/unlawful means tort relationship.

Having argued that a proper appreciation of the reliance requirement in deceit is essential to understanding the deceit/unlawful means tort relationship, I shall proceed in Section III to explain how and why the reliance component is also the key to seeing deceit as a form of relational wrongdoing. Viewing deceit in such terms is vital; for it is the conception of deceit as a form of relational wrongdoing that both distances it from the main economic torts $^{8}$ and ensures its compatibility with one of tort law's most fundamental structural norms - its bilateral nature - even if this conformity with the structural norm seems to occur at the expense of a just outcome in certain circumstances.

In section IV, I will address the question of what constitutes the gist of deceit. This enquiry will necessitate engagement with the thorny question - over which juristic opinion is divided - of whether it is best understood as a rights-based, or a loss-based, tort. Despite the fact that deceit requires the infliction of harm before it will be actionable, I shall eschew the ostensible appeal of a loss-based conception of this tort in favour of one that is rights-based. Indeed, I shall seek to show that not only is its gist not damage of an economic nature, but that there is in fact very good reason to consider it something other than a specifically economic tort (despite the prevailing tendency to characterise it as such? ${ }^{9}$.

In section $\mathrm{V}$, the focus shifts to the two aspects of this tort that seem to be regarded as unproblematic and uncontroversial in equal measure but which, on closer analysis, prove to be very uneasy bedfellows. The first of these is the fact that the contributory negligence defence is excluded from the province of this tort. The second is the fact that the mitigation rule is held to apply. The incoherence here arises from the fact that received wisdom suggests that the only real difference between the contributory negligence and mitigation principles is a temporal one. Indeed, some torts

\footnotetext{
${ }^{7}$ For treatment of some of these questions, see R. Bagshaw, "Lord Hoffmann and the Economic Torts" in P.S. Davies and J. Pila (eds.), The Jurisprudence of Lord Hoffmann (Oxford 2015).

${ }^{8}$ In the wake of $O B G v$ Allan there would seem to be just two main economic torts: causing loss by unlawful means and inducing breach of contract. Neither is bilaterally structured as both require the involvement of an intermediary.

9 Carty brackets it with what she calls the "misrepresentation economic torts" (Carty, op. cit., note 1).
} 
scholars even go so far as to argue that mitigation and contributory negligence are simply different labels applied to the very same thing. ${ }^{10}$

The article concludes in section VI, by drawing together the various strands of the preceding four sections with a view to sketching a better, more coherent understanding of the peculiarities, nature, province and theoretical basis of this grossly under-explored tort.

\section{THE NEED FOR RELIANCE}

It is generally accepted by jurists that causation is central to the law of torts at both a practical and a philosophical level. ${ }^{11}$ Perhaps oddly, however, judicial adumbrations of the tort of deceit seldom make mention of the need for causation in simple terms but insist instead upon reliance on the part of the claimant. ${ }^{12}$ In one modern case, for example, Rix L.J. set out what he took to be the four key components of the tort in this way: "The elements of the tort of deceit are ... (1) a representation, which is (2) false, (3) dishonestly made, [and] (4) intended to be relied upon and in fact relied upon". ${ }^{13}$ In Bradford Third Equitable Building Society v Borders, ${ }^{14}$ Viscount Maugham offered a more complete description of the tort. Unlike Rix L.J., he did not fail to mention the fact that, in order for this tort to be actionable, the claimant must be able to advert to consequential harm. However, leaving this difference in their respective depictions to one side for the present, it is notable that Viscount Maugham was no less keen than Rix L.J. to emphasize the need to show reliance, as opposed to causation simpliciter. According to his Lordship, the ingredients of a deceit action could be summarized thus:

First, there must be a representation of fact made by words, or, it may be, by conduct... Secondly, the representation must be made with a knowledge that it is false... Thirdly, it must be made with the intention that it should be acted upon by the plaintiff, or by a

\footnotetext{
10 See, e.g. G. Williams, Joint Torts and Contributory Negligence: A Study of Concurrent Fault in Great Britain, Ireland and the Common-Law Dominions (London 1951), 281-2: "the duty to mitigate is merely a species ... of the broad doctrine of contributory negligence". See also T. Weir, An Introduction to Tort Law (Oxford 2006), 128 (packaging the mitigation rule into the chapter on contributory negligence).

11 So central is it to the law of torts for some jurists that they either do or would afford it pride of place as the opening chapter in their textbook or treatise on the subject: see, e.g. M. Jones (ed.), Clerk and Lindsell on Torts (London 2014); R. Stevens, Torts and Rights (Oxford 2007), 303. Legal philosophers, too, have long insisted on the fundamentality of causation within tort law: see, e.g. H.L.A. Hart and T. Honoré, Causation in the Law (Oxford 1985), 1-129; W. Lucy, Philosophy of Private Law (Oxford 2007), ch. 5.

12 The oddity is not unique to deceit, however. Similar issues concerning detrimental reliance also arise in the context of negligent misstatements and the law governing misrepresentation.

13 AIC Ltd. v ITS Testing Services (UK) Ltd. [2006] EWCA Civ 1601; [2007] 1 Lloyds Rep. 555, at [251].

14 [1941] 2 All E.R. 205.
} 
class of persons which will include the plaintiff, in the manner which resulted in damage to him... Fourthly, it must be proved that the plaintiff has acted upon the false statement and has sustained damage by so doing. ${ }^{15}$

The self-same insistence on reliance, rather than causation simpliciter, is evident in the important $19^{\text {th }}$ century case of Langridge $v$ Levy, ${ }^{16}$ as well as in many other cases since then. So, what are we to make of the fact that the courts repeatedly stress the need for reliance rather than causation simpliciter? A simple, but ultimately too hasty (and therefore unsatisfactory), answer might be that the reliance component is required in deceit because representations alone do not in themselves cause harm. Rather, the words in question must be both believed by the representee, and then acted upon by him in such a way as to cause loss, before the tort can be invoked.

Despite some ostensible appeal, this answer is unsatisfactory, especially (but not exclusively) if one is attracted by the prevailing view that deceit is an economic tort. This is because the economic torts demonstrate perfectly well the fact that words alone can cause actionable loss, even in the absence of reliance on the part of the claimant. If we take the tort of malicious falsehood, for example, we discover that a claimant will be entitled to sue on just such a basis. In that tort, $D$ will have published certain false claims about $C$ to a third party from which "special damage has followed as the direct and natural result of their publication". ${ }^{17}$ This special damage will be treated as actionable loss even though there has been no detrimental reliance on the statement by $C$. It is much the same with passing off. In that tort, $D$ typically represents to would-be customers that his own product is actually a product made by $C$. A third party customer, deceived by the misrepresentation, will then buy $D$ 's product to the obvious financial cost of $C$ who would otherwise presumably have secured a sale of his own. Once again, we observe that $C$ is entitled to sue ${ }^{18}$ even though the representation was not accompanied by any detrimental reliance on $C$ s part. Finally, consider cases of three-party intimidation. In cases of this kind, $D$ will have threatened $T$ in order to coerce $T$ into causing harm to $C$; and, as the famous case of Rookes $v$ Barnard ${ }^{19}$ makes clear, $C$ will be perfectly entitled to sue $D$ for the resulting economic loss even though $C$ has not relied on anything said by $D$. It is quite enough for $C$ to show merely that $D$ 's threatening words were the cause of the relevant loss.

15 [1941] 2 All E.R. 205, 211.

16 (1837) M. \& W. 519, 531.

${ }^{17}$ Kaye v Robertson [1991] F.S.R. 62, 67 per Glidewell L.J.

${ }^{18}$ See, e.g. Warnink (Erven) BV v Townend and Sons Ltd. [1979] A.C. 731.

19 [1964] A.C. 1129. 
Against this background, one cannot help but wonder: Why, assuming that deceit is an economic tort, does it insist upon a narrower test of causation than the other economic torts? And the simple answer that words without reliance cannot cause harm, is obviously wrong. One possible, knee-jerk response to this puzzle is to suggest that deceit is somehow different because it arises only in two party settings. The point of so saying is that it sets up a distinction between deceit on the one hand and the various other economic torts just sketched, on the other, as these all require the involvement of an intermediary. But this, too, is hardly a satisfactory response, and still less an explanation. Rather, so saying merely raises the question of whether we are right in the first place to bracket deceit with the other economic torts given that all the other economic torts (including the tort of inducing breach of contract) are structurally different insofar as they require the involvement of a third party through whom the claimant is injured. ${ }^{20}$

Upon recognising that neither of these quick and easy explanations of the reliance requirement is adequate, it becomes pretty obvious that the waters of deceit are much muddier in this respect than is commonly supposed. It is clear that an altogether more careful exploration of the reliance component, together with its ramifications and possible justifications, is required. These matters occupy the remainder of this Section of the article, and all of the next Section, too.

In examining the reliance component, perhaps the first point worth stressing is this. Although the courts have consistently made clear the fact that a claimant must show loss attributable to his reliance upon the defendant's false statement, deceit is not a tort in which the need for causation is absent. It is simply that, in cases involving deceit, causation does not take the form of the default "but for" test (or any other familiar test) which makes the conduct of the defendant the primary

\footnotetext{
${ }^{20} \mathrm{It}$ is arguably the case that intimidation involving just two parties and cases of conspiracy are two-party economic torts. However, such a claim is by no means uncontroversial. I, for example, have elsewhere shown two-party intimidation to be best understood as something other than an economic tort: see J. Murphy, "Understanding Intimidation" (2014) 77 M.L.R. 33. Equally, it has been powerfully argued that unlawful means conspiracy is an otiose and anomalous cause of action given that where $A$ and $B$ combine to harm $C$ by tortious means, they could perfectly well be dealt with under the rules of joint tortfeasance (see Stevens, op. cit., note 11, pp. 248-9). The highly controversial decision in Total Network $v$ Revenue and Customs Commissioners [2008] UKHL 19; [2008] 1 A.C. 1174 (allowing common law crimes to count as unlawful means) is the only obstacle to dealing with such cases in this way. Finally, lawful means conspiracy is anomalous because it renders tortious the doing of something by two or more people that would be a lawful thing to do by any one of them acting alone.
} 
point of focus in seeking to explain the occurrence of harmful event $X .^{21}$ Instead, causation is determined primarily by reference to the claimant's conduct: his detrimental reliance. Notwithstanding this observation, it would be a grave mistake to suppose that reliance is merely a synonym for "causation" as that term is commonly understood. This is because reliance comprises an appreciably narrower-than-usual form of causation. ${ }^{22}$ The difference between reliance and causation simpliciter is most obvious, as Goldberg, Sebok and Zipursky have pointed out, ${ }^{23}$ in cases where $D$ deceives a third party, $T$, into acting in such way that loss is ultimately caused to $C$. In such three-party cases, the party who suffers the loss cannot invoke the tort of deceit against the statement-maker since, although his loss was caused by the defendant's false representation, it was not caused by his reliance upon that statement. ${ }^{24}$ This very point was, as Goldberg et al identify, central to the decision in the American case of Pegram $v$ Hebding. ${ }^{25}$

The claimant in that case was dismissed by his employer in consequence of the defendant having told the employer certain untruths about the claimant. It was held that the claimant had no cause of action in fraud. The reason for so holding was that the claimant had not personally relied upon, and had therefore never been deceived by, the defendant's lies. Although the defendant's lies had caused the claimant's loss, the absence of reliance on the part of the claimant was fatal to his successfully pursuing an action for fraud. Accordingly, as Goldberg et al quite properly conclude, it is clear that reliance and ordinary (that is to say, defendant-centred) causation come apart in the context of the American common law tort of fraud. Importantly for present purposes, the very same observation can be made, with equal pertinence, in relation to the English law of deceit. Yet, however illuminating this observation is in its own right, it is by no means the end of the matter. This is because insistence upon reliance in the tort of deceit gives rise to what is arguably an anomaly in English law. ${ }^{26}$ I say "arguably" because it is only likely to be seen as an anomaly by those who

${ }^{21}$ For the argument that the "defendant's involvement" is something like a golden thread running throughout all legal usage of the term causation, see Stapleton, op. cit., note 4.

${ }^{22}$ For discussion of reliance as a special form of causation, see C. Witting, "Duty of Care: An Analytical Approach" (2005) 25 O.J.L.S. 33, 56; K. Barker, "Unreliable Assumptions in the Modern Law of Negligence” (1993)109 L.Q.R. 461, 480 .

${ }^{23}$ J.C.P. Goldberg, A.J. Sebok and B.C. Zipursky, "The Place of Reliance in Fraud” (2006) 48 Arizona L. Rev. 1001.

24 At the same time, the intermediary who is lied to may suffer no harm and accordingly she, too, will have no available action in deceit: see, e.g. National Phonographic Co. Ltd. v Edison-Bell Consolidated Phonograph Co. Ltd. [1908] 1 Ch. 335.

25667 So. 2d 696 (Ala. 1995).

${ }^{26}$ Describing the observation of Goldberg et al as "limited" is probably unfair. After all, these authors (writing in 2006) never actually set out, and never could have set out, to consider the ramifications of the insistence upon reliance for the web of protection offered by English common law in the post-OBG $v$ Allan era. 
consider deceit to be an economic tort and who favour an interventionist, as opposed to a minimalist, approach to the economic torts. ${ }^{27}$

For such thinkers, the anomaly consists in the fact that, because deceit requires proof of reliance (and can therefore only be invoked in a two-party setting ${ }^{28}$ ), a gap in the web of common law protection can be seen to exist. This gap is by no means an obvious one. But the fact that it is to some extent hidden does not detract from the fact that its existence provides good reason to think hard about whether it is appropriate to persist with the reliance requirement in deceit. In order fully to appreciate the problem, it is necessary to understand the nature of the relationship between the tort of deceit and the tort of causing loss by unlawful means as re-configured by the House of Lords in $O B G v$ Allan. And in order to gain such an understanding, it is useful to consider quite closely two cases which serve to illuminate it. The cases are National Phonographic Co Ltd. v Edison-Bell Consolidated Phonographic Co Ltd., ${ }^{29}$ and Rosen v Spanierman. ${ }^{30}$

In National Phonographic, $A$ 's deliberate, false representation to $B$ ( $C$ s agent) persuaded $B$ to act in a way that, although not harmful to $B$ himself, was nonetheless financially damaging to $C$. Just as in Pegram $v$ Hebding, the court held that because $C$ had not personally relied upon $A$ 's misrepresentation, he could not invoke the tort of deceit to sue $A{ }^{31}$ On the other hand, $C \operatorname{did}$ not end up without a remedy. He was able, instead, to rely upon what is nowadays referred to as the tort of causing loss by unlawful means. The fact that deceit employs a narrow test of reliance (as opposed to causation simpliciter) made little practical difference. In the wake of $O B G v$ Allan, however, things could now be very different.

In his leading speech in $O B G$, Lord Hoffmann laid down an important control mechanism affecting the ability of third parties to sue when loss is caused via an intermediary (which was, of course, what occurred in National Phonographic). According to this new mechanism, a right of action can only be maintained on the basis of the unlawful means tort where there has been an "unlawful

\footnotetext{
27 The interventionist conception of the economic torts sees their role as being "to provide a remedy for intentional economic harm caused by unacceptable means": OBG v Allan [2008] UKHL 19; [2008] 1 A.C. 1, at [153] per Lord Nicholls. On this view, only a relatively low threshold need be crossed in order to invoke these torts. By contrast, minimalists think that aggressive, competitive, financially injurious commercial behaviour should ordinarily be tolerated and that protection should be available only on very narrowly defined grounds. Defences of minimalism can be found in the following: H. Carty, "Intentional Violation of Economic Interests: The Limits of Common Law Liability" (1988) 104 L.Q.R. 250) and L. Hoffmann, "The Rise and Fall of the Economic Torts" in S. Degeling et al, (eds.), Torts in Commercial Law (Sydney 2001).

${ }^{28}$ In saying this, and in line with the law of agency, I regard a misrepresentation made by $D$ to $C$ s agent, but duly passed on to $C$, as being a two-party case.

${ }^{29}$ [1908] 1 Ch. 335.

30894 F. 2d 28 (2d Cir. 1990).

31 [1908] 1 Ch. 335, 351-352 per Joyce J.
} 
interference with the actions of a third party in which the claimant has an economic interest'. ${ }^{32}$ As such, in cases where $D$ lies to $T$ and $T$ then acts to $C$ s detriment in circumstances where $C$ lacks the requisite economic interest in T's actions, $C$ will have no claim based on either deceit or the unlawful means tort. The economic interest requirement debars a claim using the unlawful means tort; and the need to show reliance by $C$ in deceit renders that tort unavailable.

To be clear, nothing said in $O B G \vee$ Allan would have affected the outcome of National Phonographic had the facts of that case occurred after $O B G$. The defendant's false representation to the intermediary in National Phonographic was potentially a tort against the intermediary, hence satisfying Lord Hoffmann's first requirement for the unlawful means tort that there must be an "unlawful interference with the actions of a third party". ${ }^{33}$ Equally, since the relationship of principal/agent existed between the claimant and the lied-to third party in that case, his Lordship's second requirement - that the claimant must have an economic interest in the actions of the intermediary - was also satisfied. However, it is not hard to imagine a case in which no such relationship exists between the claimant and the intermediary; and indeed, American jurisprudence furnishes just such an example.

In Rosen v Spanierman, an art dealer informed a married couple, Mr and Mrs Rosen, that a certain painting that he owned had been painted by a famous artist. Impressed by its alleged provenance, the couple considered the stated price of $\$ 15,000$ to be a fair one. They therefore agreed to take the picture and informed the dealer that the bill should be sent to the wife's mother, Mrs Lipson, who had agreed to buy the painting for them as an anniversary present. When, subsequently, the truth about the painting was discovered, Mrs Lipson attempted to sue the dealer for fraud, basing her claim on the dealer's lies about the authenticity of the painting. Her action in fraud failed even though the defendant's lies were the cause of her loss.

If such a case were to arise in this country, the person in the place of Mrs Lipson would fare no better. Here, too, the absence of reliance on that person's part would be fatal to an action in deceit. But on top of that, any attempt on their part to invoke the unlawful means tort would also fail since, among other things, ${ }^{34}$ unlike the National Phonographic case, that person would be unable to show the requisite economic interest in the third party (the person in the place of the Rosens). At this point the apparent gap in the web of common law protection referred to earlier becomes clear.

32 [2008] UKHL 19; [2008] 1 A.C. 1, at [47].

33 But note that mere potential civil liability towards the intermediary fell within Lord Hoffmann's specific definition of unlawfulness in this context: OBG v Allan [2008] UKHL 19; [2008] 1 A.C. 1, at [49].

${ }^{34}$ Another obstacle would be that the dealer almost certainly did not have the requisite intention to cause loss to Mrs Lipson. On the need for such intention, see OBG v Allan [2008] UKHL 19; [2008] 1 A.C. 1, at [62] per Lord Hoffmann. 
Tort law imposes no liability on $D$ even though $D$ secures an ill-gotten gain from $C$ by the indirect means of deliberately deceiving a third party. For some jurists, as already noted, the non-availability of a tort remedy in such circumstances is anathema. Put more fully: they consider the absence of tort law's protection for someone in Mrs Lipson's position to be inconsistent with the widely acknowledged conception of tort law as a morally grounded body of rules and principles of interpersonal responsibility for harm-doing. ${ }^{35}$ There can be no denying that when $X$ lies to $Y$ in order to make an indirect gain (reflected in a loss to $Z$ ), $X$ engages in immoral conduct for which $X$ is clearly responsible in the relevant sense (i.e., it was volitional conduct).

Now, one possible solution to this apparent problem - let us call it Option 1 - would be to abandon Lord Hoffmann's insistence upon an economic interest on the part of the claimant vis-à-vis the third party in cases involving the unlawful means tort. Another, very different response - Option 2 - would be to abandon the need for reliance in the tort of deceit in favour of a more familiar, defendant-centred, test of causation. However, since the prospect of Option 1 being adopted is negligible (for reasons given in the next Section of this article), the question of whether the tort of deceit ought to embrace a more usual, defendant-centred test of causation instead of reliance naturally arises. Put otherwise, having illuminated the relationship between the unlawful means tort and deceit, we are forced to confront the fact that the reliance component in deceit is rather more problematic than it is ordinarily assumed to be. Can we, then, offer any kind of defence of the reliance requirement - if not from a practical perspective, then at least from a theoretical one?

\section{THEORETICAL JUSTIFICATION OF THE RELIANCE REQUIREMENT}

As already stated, I think it is impossible that the problem of someone like Mrs Lipson being left without a remedy under English law will be solved by Option 1. Such a change in the law would necessitate the abandonment of Lord Hoffmann's requirement in OBG v Allan that, in the context of the unlawful means tort, there must always be "a wrongful interference with the actions of a third party in which the claimant has an economic interest". ${ }^{36}$ However, this "gloss" (as it has been dubbed $^{37}$ ) on the idea that the unlawful means tort involves no more than the intentional infliction

\footnotetext{
${ }^{35}$ For this conception of tort law, and details of leading jurists who subscribe to it, see P. Cane, "Reforming Tort Law in Australia: A Personal Perspective” (2003) 27 Melb. Univ. L. Rev. 649, 671.

${ }^{36}$ OBG v Allan [2008] UKHL 19; [2008] 1 A.C. 1, at [47]. For detailed analysis of this requirement, see Bagshaw op. cit., note 7 .

37 The term belongs to Carty, op. cit., note 1, p. 95.
} 
of economic loss via unlawful means and a third party, ${ }^{38}$ was no mere slip of the judicial pen. Rather, it formed a central part of the decision in Douglas $v$ Hello! Ltd. ${ }^{39}$ (which case was one of two other consolidated appeals heard alongside $O B G v$ Allan). In Douglas, the House of Lords was adamant that no remedy should be afforded to the claimant precisely because the claimant was unable to show an economic interest in the actions of the intermediary. ${ }^{40}$

There, an undercover photographer sold to the defendants certain photographs that he had surreptitiously taken at the wedding of Michael Douglas and Catherine Zeta-Jones. The photographs were subsequently published in Hello! magazine despite the Douglases having granted the exclusive right to publish such photos to its rival, $O K !$ magazine. All other photography at the event had been forbidden. Among various other arguments, $O K !$ alleged that there had been commission of the unlawful means tort. However, although Lord Hoffmann was prepared to accept that the requisite intention to injure Hello! was present, ${ }^{41}$ he stood firm against the suggestion that there had been any injurious interference with the commercial relations that existed between the claimants and the Douglases. No claim based on the unlawful means tort could be pursued since:

[n] either Mr Thorpe [the photographer] nor Hello! did anything to interfere with the liberty of the Douglases to deal with $O K !$ or perform their obligations under their contract. All they did was to make OK? s contractual rights less profitable than they would otherwise have been. ${ }^{42}$

In referring to "the liberty of the Douglases to deal with $O K$ ?", his Lordship was giving specific content to the economic interest requirement that he had described in only very general terms, earlier in his speech. Put otherwise, the requisite economic interest was specifically defined in terms of the intermediary's "freedom to deal with the claimant". ${ }^{43}$

\footnotetext{
${ }^{38}$ For the argument that, historically, the "gloss" was not required and that the tort contained only three elements - i.e., intention, unlawful means and resulting harm - see D. Stilitz and P. Sales, "Intentional Infliction of Harm by Unlawful Means" (1999) 115 L.Q.R. 411, 436.

${ }^{39}$ [2008] UKHL 19; [2008] 1 A.C. 1, at [129]-[136].

40 In view of this, we can dismiss the alternative "gloss" offered by Lord Nicholls in OBG v Allan along the lines that, in addition to the core requirements of (1) intention, (2) unlawful means and (3) harm, $C$ must also be able to show that he was harmed "through the instrumentality of a third party": [2008] UKHL 19; [2008] 1 A.C. 1, at [159]. As Lord Walker pointed out, Lord Nicholls' approach would, contrary to authority, usher in a test of simple causation: see, ibid., at [269]. 41 [2008] UKHL 19; [2008] 1 A.C. 1, at [136].

42 Ibid., at [129].

43 Although his Lordship's speech is not crystal clear on the question of whether the liberty of $C$ to deal with the Douglases was being used as a synonym for the more general requirement that there must be an economic interest on the part of $C$ in $D$, it nonetheless seems the best interpretation of his Lordship having placed such weight upon it. This
} 
Importantly, a claimant's interest in having the unfettered freedom to deal with a third party is observably different in kind from a purely parasitic or contingent interest in the financial affairs of that intermediary. In making the necessary interest a mutual economic freedom on the part of the claimant and the third party to deal with one another, Lord Hoffmann's "gloss" on the requirement of intentionally inflicted harm operates, in the words of Lord Walker, as an important "control mechanism ... [making] disruption caused as between the third party and the claimant [a prerequisite of liability]". ${ }^{44}$ More pertinently, it also helps give that tort its specifically economic flavour. Accordingly, it easy to understand why the unlawful means tort cannot now be invoked by someone like the claimant in Rosen $v$ Spanierman, while it can be engaged in a case like Lonrbo plc v Fayed. ${ }^{45}$

In the latter case, the defendant's lies to the intermediary specifically led to the claimant being prevented from securing a contract with the intermediary. Crucially, there was an interference with the claimant's liberty to deal commercially with that intermediary. In Rosen $v$ Spanierman, by contrast, there was absolutely no interference with the freedom of Mrs Lipson and the Rosens to make whatever commercial arrangements they wanted as between themselves. Mrs Lipson would not, in short, be a claimant who could satisfy the requirement embodied in Lord Hoffmann's control mechanism. She would, as noted earlier, be left without a remedy under both the tort of deceit and the unlawful means tort.

Now, given that the decision in Douglas stands not just on House of Lords authority, but House of Lords authority that constitutes the leading case on the economic torts, it seems extremely unlikely that the courts will abandon the control mechanism laid down there for cases involving the unlawful means tort. This, of course, does nothing to assuage the concerns of those who advocate an interventionist role for the economic torts - that is, one according to which "in addition to ... protecting property and contract rights ... [these torts] set limits to rivalrous behaviour". ${ }^{46}$ For jurists of this stripe, Douglas highlights a serious gap in the common law because it threatens to leave remediless those claimants who are financially harmed by the intentional, injurious conduct of an

is because he made clear the fact that the unlawful means tort would not be available to anyone who merely suffered loss by virtue of "acts which may be unlawful against a third party but which do not affect his freedom to deal with the claimant”: [2008] UKHL 19; [2008] 1 A.C. 1, at [136]. Others who share this interpretation include Carty, op. cit., note 1, pp. 96-98 and S. Deakin and J. Randall, "Rethinking the Economic Torts" (2009) 72 M.L.R. 519, 533.

44 [2008] UKHL 19; [2008] 1 A.C. 1, at [269]. Lord Hoffmann was at pains to explain that both RCAv Pollard [1983] Ch. 135 and Oren $v$ Red Box Toy Factory Ltd. [1999] FSR 785 should be understood this way. In both cases $D$ caused loss to $C$ via a wrong committed to an intermediary but only in a way that "did not interfere with the [intermediary's] liberty of action with respect to the plaintiff': ibid., at [53].

45 [1990] 2 Q.B. 479. Lord Hoffmann specifically made clear that he saw this case as falling within the purview of the unlawful means tort in OBG v Allan [2008] UKHL 19; [2008] 1 A.C. 1, at [50].

${ }^{46}$ Deakin and Randall, op. cit., note 43, 532. 
economic rival in certain circumstances. ${ }^{47}$ Whether this is a fair criticism of Douglas is a matter over which interventionists and minimalists will no doubt lock antlers at some point in the future. It is not, however, a question upon which I need dwell here, since the present study is concerned principally with the tort of deceit. The tort of causing loss by unlawful means is of only tangential interest. It concerns us only insofar as it helps to highlight certain important qualitative differences that exist between it and the tort of deceit with which it is commonly, yet unthinkingly, bracketed as a fellow economic tort. No attempt to justify the particular ingredients of the unlawful means tort is therefore warranted or proffered here. Rather, my adverting to Lord Hoffmann's economic interest requirement - spelled out and applied in OBG/Douglas - is necessary only for the purpose of contextualising the significance of the question at the heart of Option 2: whether we should modify the tort of deceit so as to make causation simpliciter (rather than reliance) the appropriate touchstone of liability.

There are two possible bases for the argument that the tort of deceit ought to be changed in this way. The first is that, as it presently stands, deceit is anomalous inasmuch as it eschews the defendant-centred approach to causation that is generally used within tort law. The second is that the reliance requirement causes the tort of deceit to clash with the moral foundations of tort law by denying a remedy to those who become victims of another's mendacious profiteering in certain circumstances. Put more concretely, if the reliance requirement were to be replaced by the more familiar test of causation simpliciter, deceit would extend its protective reach to cases like Rosen $v$ Spanierman.

So, is there a case for replacing the current reliance component in deceit with the more familiar tort law requirement of defendant-centred causation? Tempting though it may be to answer this question in the affirmative - especially in the light of the argument that, without such a change, there will remain a gap in the web of protection supplied by the common law - I nonetheless suggest that the better answer is, "no". My reasoning is as follows.

Tort law is - as many leading, contemporary tort theorists are at pains to stress ${ }^{48}-$ overwhelmingly characterised by, and thus best understood in terms of, relational, not bare wrongs. Put otherwise, tort law for the most part comprises a body of wrongs that are bilaterally structured and involve the breach of a legal duty owed by defendant $X$ to claimant $Y$. It is not normally enough that $X$ has merely, in some very basic (moral) sense, acted wrongfully. Nor is it invariably enough

\footnotetext{
${ }^{47}$ In Douglas itself, $C$ did not ultimately go without a remedy since an action for breach of confidence was available. 48 These include E.J. Weinrib, The Idea of Private Law (Cambridge, Mass. 1995), 1-2; Stevens, op. cit., note 11, p. 173; N.J. McBride and R. Bagshaw, Tort Law (London 2012), 9-13.
} 
that $X$ has simply caused harm or loss to $Y$ by virtue of his intentional (by which I mean only, volitional) conduct. For an act to be tortious, it must ordinarily have been wrongful towards $Y$ (or a class of persons to which $Y$ belongs). Benjamin Zipursky, a leading proponent of the relational nature of tort law, has expressed the matter this way:

The wrongs of tort law spring from relational directives, not simple directives. To commit the tort of trespass is to trespass upon someone's land; to commit the tort of fraud is to defraud someone out of something; to commit the tort of libel is to defame someone through the written word, and so on... Criminal law need not be like this. Littering, perjury, obstruction of justice, conspiracy to traffic in narcotics - all of these are arguably breaches of simple directives, not relational directives. They are simple wrongs. ${ }^{49}$

As presently defined, and as noted by Zipursky in the quotation above, the tort of deceit conforms to this structural norm. The relational nature of the wrong is secured precisely because of the reliance requirement. Were this element of the tort to be replaced by a test of causation simpliciter, this conformity with the structural norm of tort law would be lost and tort law would be rendered less coherent as a result. But since coherence is generally considered to be a virtue (and therefore a worthwhile aspiration) within the law of torts, ${ }^{50}$ there exists a strong theoretical case for retaining the ostensibly odd, but structurally compliant, requirement of reliance in deceit. Furthermore, although departure from this structural norm would permit this tort to fill the regulatory "gap" that appears to exist in English law, it is by no means obvious that the "gap" exposed by cases such as Rosen v Spanierman ought to be filled in this way. ${ }^{51}$ The choice, at bottom, is one between conformity with tort law's structural norm ${ }^{52}$ on the one hand (with all that that brings with it by way of coherence), and a desire to fill what interventionists would consider to be a regulatory gap, on the other. I would suggest that, although there are undoubtedly quite a number of established exceptions to the

${ }^{49}$ B.C. Zipursky, "Civil Recourse and the Plurality of Wrongs: Why Torts are Different" [2014] New Zealand L. Rev. $145,149$.

${ }^{50}$ See, e.g. Weinrib, op. cit., note 48, pp. 12-14; A. Beever, Rediscovering the Law of Negligence (Oxford 2007), 24.

${ }^{51}$ The loss suffered is typically of the economic variety; and there is no right to economic welfare generally recognised by tort law. Furthermore, the size of the gap must not be over-estimated. Lies designed to secure a competitive advantage over C, as in Lonrbo v Fayed, might well result in liability for malicious falsehood: Wilts United Dairies $v$ Robinson [1957] R.P.C. 220, 237.

${ }^{52}$ For a powerful defence of this norm, see J.C.P. Goldberg and B.C. Zipursky, “Torts as Wrongs” (2010) 88 Texas L. Rev. 917. 
structural norm of tort law, ${ }^{53}$ the mere existence of these exceptions forms a very poor platform from which to mount the case for uncoupling yet another area of the law that is currently consistent with that norm. ${ }^{54}$ This would be a classic case of the tail wagging the dog. It would leave tort law less coherent than it presently is. ${ }^{55}$ Equally, I do not think it much of an objection to the reliance requirement that it seems not to have its origins in a concern to ensure conformity with the structural norm of tort law, but rather in early contract law (covenant) wherein a remedy was made available to those who relied to their detriment upon another's false warranty. ${ }^{56}$ Sometimes, historical quirks (such as this one) have a beneficial effect; and for this reason they ought not to be undone.

To sum up so far, although the reliance component in deceit is usually treated cursorily by jurists - presumably because they think it fulfils an unproblematic function - it in fact plays a contentious, but nonetheless vital, role in ensuring that deceit is bilaterally structured. That is, it ensures that deceit is available not merely because loss has been caused but because $A$ can properly be said to have committed a wrong against $B$. In this respect, then, deceit is just like most other torts. However, even if the reliance component can be explained and justified in this way, there still remain - at least on the surface - several respects in which this tort is apt to appear unusual.

According to conventional wisdom, deceit is an economic tort concerned with the protection of purely economic interests; and its gist is usually portrayed as being the infliction of economic loss. These are problematic matters because the default position in English law is that there is no general, exigible right not to have economic losses inflicted upon one and because the idea that torts are best seen as loss-based (rather than rights-based) has so powerfully been

\footnotetext{
${ }^{53}$ For a range of examples, see J. Murphy, "Rights, Reductionism and Tort Law" (2008) 28 O.J.L.S. 393; J. Goudkamp and J. Murphy, "Tort Theories and Tort Statutes" (2014) 131 L.Q.R. 133, 147-9.

54 That there is, more generally, a need for relational wrongdoing in this area is in part borne out by the fact that an infringement of the Restrictive Trade Practices legislation does not ground an action for breach of statutory duty. The absence of such an action can be explained by reference to the fact that an infringement of the legislation does not involve the commission of a relational wrong towards someone else. Cf Hazel Carty's explanation: that these regulatory (i.e., minor criminal law) wrongs afford no tort action because the economic torts are "simply [about] widening the parties to a civil action"; and because the economic torts are parasitic upon some other form of wrong "already recognized by the civil law" (Carty, op. cit., note 1, p. 174). This explanation fails because it is circular. It presupposes the very thing in issue: whether the commission of a regulatory wrong can provide a basis for a claim in tort. On Carty's analysis, the reason why breach of the legislation does not ground a civil action is because the breach of the legislation does not ground a civil action.

${ }^{55}$ For a wonderful, if brief, exploration of the extent to which tort law is rightly characterized as incoherent, see J.C.P. Goldberg, "Ten Half Truths About Tort Law" (2008) 42 Valparaiso U. L. Rev. 1221, 1222-1224.

56 See D. Ibbetson, A Historical Introduction to the Law of Obligations (Oxford 1999), 84-85; Carty, op. cit., note 1, p. 182.
} 
demolished of late. ${ }^{57}$ It is to these two matters - along with the scope of the tort - that the focus of this article now shifts.

\section{THE GIST AND PROVINCE OF DECEIT}

Because deceit is not actionable per se, it is sometimes said that damage to the claimant forms "the gist of the action". ${ }^{58}$ On this view - which is reminiscent of what Viscount Maugham said about the need to prove tangible loss in Bradford Third Equitable Building Society v Borders ${ }^{59}$ - the tort of deceit may be thought to lend support to what Robert Stevens calls the "loss-based model of tort law". ${ }^{0}$ This is not, however, the model of tort law to which Stevens himself subscribes; and nor is a lossbased conception of deceit the one that Stevens favours. In his view, deceit is firmly a rights-based tort: he considers its gist to be "our right not to be lied to". ${ }^{61}$ To this basic proposition, however, Stevens attaches an addendum which purports to explain the courts' repeated insistence on the need to prove harm in this tort. Since, "[i]t would, of course, be unacceptable for the law to make actionable all of the minor deceptions that we practise upon one another", ${ }^{62}$ there is also, he argues, a need for the claimant to show consequential loss. Under analysis, however, this addendum reads more like empty rhetoric than a sound explanation of the law. This is because Stevens conspicuously fails to offer any practical or theoretical explanation for his assertion that that it would "of course, be unacceptable" for the law to make all such lies actionable. The most obvious explanation for his thinking this way is that making all minor deceptions actionable would lead to a floodgates problem. ${ }^{63}$ But floodgates concerns have no place in Stevens' theory of tort law. Indeed, he goes to very great lengths in his monograph, Torts and Rights, to discredit the role of policy-based reasoning

\footnotetext{
${ }^{57}$ See especially, Stevens, op. cit., note 11; Goldberg and Zipursky, op. cit., note 52. But note that there is a world of difference between (correctly) stating that that tort law is not best seen as being loss based and (incorrectly) saying that there are no loss based torts. For examples of certain loss-based torts, see Murphy, op. cit., note $\mathbf{5 3 .}$

${ }^{58}$ Carty (op. cit., note 1, p. 188) erroneously attributes this interpretation to the speech of Lord Blackburn in Smith $v$ Chadwick (1884) 9 App. Cas. 187, 190. However, his Lordship - whose speech only begins at p. 192 - never actually said this. The closest that he came to such a remark was when he said "[w]hatever difficulties there may be as to defining what is fraud and deceit, I think no one will venture to dispute that the plaintiff cannot recover unless he proves damage": ibid., at 195. The exact same mistaken attribution appears in Jones (ed.), op. cit., note 11, p. 1311.

${ }^{59}$ In the wholesale review of the economic torts undertaken in $O B G v$ Allan, Lord Hoffmann reiterated that $C$ must have suffered tangible loss before she will be able to invoke the tort of deceit: [2008] UKHL 19; [2008] 1 A.C. 1, at [49].

${ }^{60}$ On this model, "the defendant should be liable where he is at fault for causing the claimant loss unless there is a good reason why not": Stevens, op. cit., note 11, p. 1.

${ }^{61}$ Stevens, op. cit., note 11, p. 8.

${ }^{62}$ Stevens, op. cit., note 11, p. 89.

${ }^{63}$ Explicit recognition of this apparent floodgates problem can be found in J.C.P. Goldberg and B.C. Zipursky, "The Fraud on the Market Tort" (2013) 66 Vanderbilt L. Rev. 101, 117-118.
} 
in tort law. ${ }^{64}$ And floodgates considerations are nothing if not a type of policy concern. Yet if floodgates considerations do not explain his stance with respect to the need to show loss, it is a mystery as to what other grounds Stevens may have for thinking it self-evident that the law cannot treat as actionable all the minor deceptions that people practise upon one another.

Happily, there is no need for me to attempt to unearth a more robust defence of this claim, or of his more general submission that what underpins the tort of deceit is the "right that each of us has not to be lied to ... [which is] only actionable upon proof of consequential loss". ${ }^{65}$ This is because his position is inconsistent with legal history as well as with what appears to be the current state of the law.

First, consider the law. In the famous case of Wilkinson $v$ Downton, ${ }^{66}$ the claimant sought (among other things) to sue in deceit in respect of the shock-induced illness she suffered as a consequence of the defendant's practical joke. The defendant had untruthfully told her that her husband had suffered a very severe injury in an accident. As a consequence of this practical joke, the claimant suffered a serious physical reaction. However, Wright J. refused to allow the claim in respect of her illness in so far as it was framed in terms of deceit. ${ }^{67}$ Although Mrs Wilkinson was lied to, and although she also suffered a consequential loss, no remedy was available to her on this basis. Wilkinson v Downton is therefore inconsistent with, and indeed contradicts, Stevens' account of what undergirds this tort: a right not to be lied to that is actionable upon proof of consequential loss. ${ }^{68}$

If we look to even older authorities than Wilkinson $v$ Downton, we find there further reason to doubt Stevens' presentation of the harm requirement in deceit as a sort of pragmatic control device. The modern tort of deceit evolved from an action on the case in which the proof of recognised harm or damage was the central component. ${ }^{69}$ This fact is important when one bears in mind that there was no pre-ordained scheme of rights which governed the development of actions on the case. ${ }^{70}$ Instead, the courts proceeded in very much an ad hoc fashion, granting remedies to any number of different forms of loss whenever they considered it appropriate so to do. The suffering of loss or harm was the centrepiece of such actions. It was no mere added extra, or control mechanism. Accordingly, both extant authority and legal history are at odds with Stevens'

\footnotetext{
${ }^{64}$ Stevens, op. cit., note 11, ch. 14.

65 Ibid.

${ }^{66}$ [1897] 2 Q.B. 57.

${ }^{67}$ Ibid., at p. 58.

${ }^{68}$ The case also reinforces the point made earlier regarding the need for reliance rather than causation simpliciter since $C$ s illness was directly caused by the substance of $D$ 's message rather than by her acting in reliance on what was said to her.

${ }^{69}$ 'The action on the case itself evolved from the early law of covenant, but this is immaterial for present purposes.

70 See S.F.C. Milson, Historical Foundations of the Common Law (Oxford 1981), 300-305.
} 
understanding of deceit. Yet again, with this most inscrutable of torts, we discover that there is a good deal more to be understood than initially meets the eye. Another simple and ostensibly plausible explanation for a prominent feature of this tort - the requirement of harm - can be seen to founder when subjected to proper scrutiny.

An alternative, rights-based understanding of the modern tort is, however, available. It belongs to Goldberg, Sebok and Zipursky. In contrast to Stevens - who identifies as the gist a bare right not to be lied to - these theorists suggest, somewhat periphrastically, that the right in play is some rather hazy right to decision-making autonomy. They put it this way:

$[T]$ he core of the legal wrong that has historically been labeled "fraud" or "deceit" is the wrong of interfering with a particular interest of the victim, namely her interest in making certain kinds of choices in certain settings free from certain forms of misinformation. $^{71}$

Although in some respects helpful, this too is an inadequate description of the gist and province of deceit. For, while there is nothing in this depiction of the tort that is contradicted by either the existing law or legal history, it obviously fails as a serviceable definition. It is far too opaque since the references to "certain kinds of choices", "certain settings" and "certain forms of misinformation" do little, if anything, to elucidate the precise scope and concern of deceit. Instead, defining its gist and province in this way merely causes us to wonder: What kinds of choices? Which settings? What kinds of misinformation?

Despite its opacity, however, we need not dismiss this definition out of hand. For, although clearly deficient as it stands, it can nonetheless be taken as a useful platform from which to construct a much more helpful understanding. To begin with - at least as a matter of English law - we can strip away entirely the qualifier "certain forms of misinformation". This is because, in this country (if not the USA, from where Goldberg et al hail), the types of misinformation which count for the purposes of deceit are tolerably well settled. We could, then, simply replace the last six words in their definition with the phrase "free from the kinds of misrepresentation laid down in Derry v Peek". 72

\footnotetext{
${ }^{71}$ Goldberg, Sebok and Zipursky, op. cit., note 23, 1011. Although the talk here is of the "wrong of interfering with a particular interest of the victim", it is clear from the authors' other work that they consider the wrongs of tort law to be rights infringements: see, e.g. Goldberg and Zipursky, op. cit., note $\mathbf{5 2}$.

${ }^{72}$ In Derry $v$ Peek (1889) 14 App. Cas. 337, 374 Lord Herschell laid down the test, still applied today, that only a misrepresentation that "has been made (1) knowingly, or (2) without belief in its truth, or (3) recklessly" will be caught by the tort.
} 
It is similarly unclear how much weight we need attribute to the authors' claim that deceit is only available in "certain settings". In the course of their 27 page article, they themselves only refer to the qualifier, "certain settings", twice; and on neither occasion do they offer any positive elaboration of what these settings might be. Instead, they make only the negative claim that there is no a priori reason why deceit should be confined to what the authors call the "exchange setting". ${ }^{73}$ So, in effect, they advance two related, yet substantially different, claims in this regard. The first is that deceit may only be invoked in a limited range of settings. The second is that this tort is not confined to the exchange setting. Taken together, these two assertions do nothing to clarify the province of deceit. So can we improve upon this? Arguably we can. For, some assistance in understanding the scope of deceit may be gleaned - in England at least - from what seems to be logically implied by the decision in East v Maurer. ${ }^{74}$

In that case, the defendant owned two hairdressing salons. He offered to sell one to the claimants who hoped to set up in the hairdressing business. The defendant assured the claimants that he had no intention of working in his remaining salon unless a staffing emergency arose. This assurance was a material consideration for the claimants who were fearful that the first salon's existing clientele would simply defect (because of their prior personal connections with the defendant), to the defendant's second salon after the sale of the first. As things transpired, the defendant sold the first salon to the claimants but, contrary to his assurance, did continue to work in the second salon. The claimants' fears about customer loyalty causing a loss of business were realised. The claimants successfully sued for deceit in respect of the losses they suffered. Among the losses that were held to be compensable was a sum reflecting the opportunity cost associated with buying the defendant's first salon instead of another hairdressing salon, elsewhere. It was perfectly proper, said Beldam L.J., for the damages awarded to take into account "the kind of profit which the second plaintiff might have made if the representation which induced her to buy the [first salon] ... had not been made, and that involved considering the kind of profits which she might have expected to make in another hairdressing business bought for a similar sum", ${ }^{75}$

The focus of this decision upon the opportunity cost attributable to the defendant's false statement arguably helps clarify the range of circumstances in which the tort of deceit might be invoked. On the logic of East $v$ Maurer, it might be argued that any fraudulently induced course of

\footnotetext{
${ }^{73}$ Writing about exchange settings, the authors state that, "it is not obvious to us that this sort of case exhausts the domain of fraud”: Goldberg, Sebok and Zipursky, op. cit., note 23, 1011.

74 [1991] 2 All E.R. 733.

$75 \mathrm{Ibid}$, at 467. Essentially the same reasoning underpins the decisions in Clef Acquitaine SARL v Laporte Materials (Barrow) Ltd. [2001] Q.B. 488 and Parabola Investments Ltd. v Browallia Cal. Ltd. [2010] EWCA Civ 486; [2011] Q.B. 477.
} 
action, quite regardless of the setting in which the deceitful statement is made, has the potential to carry with it the chance to sue in deceit so long as measurable loss results therefrom. This is not to say, of course, that any deception at all which induces $C$ to do $\varphi$ will be actionable. $C$ must still bear the burden of proving the resulting loss. And such proof will typically require $C$ to show not merely that doing $\varphi$ caused her loss, but also that she would have done not- $\varphi$ had she not been deceived into doing $\varphi$.

If this analysis is correct, then the second of the qualifiers in the Goldberg et al definition also becomes otiose; for we can disregard as unfounded the claim that deceit is only available in "certain settings". On the logic of East v Maurer, deceit is in principle available in any circumstances in which $D$ 's untruthful statement causes $C$ to do $\varphi$ (the doing of which results in loss to $C$ ) and $C$ can show that had she not been misled she would have done not- $\varphi$. Put otherwise, there seems no logical limit on the circumstances in which loss might be caused by being induced to do $\varphi$ (so long as there

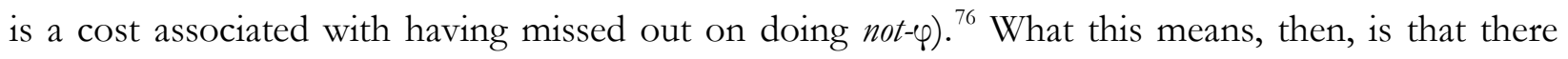
remains only one ambiguity in the definition of the gist and scope of deceit proffered by Goldberg $e t$ al that needs to be considered: the reference to "certain types of choices".

Even here, though, it is possible to be more precise. We have already identified the fact that deceit requires a claimant to show measurable loss. We might therefore abandon the reference to "certain types of choices" (whatever they may be) and say the following instead: Deceit requires the claimant to have made a choice in reliance on the defendant's untruthful statement which results in some recognised form of harm for the claimant. This, again, is borne out by the case law. In Wilkinson v Downton, Wright J. made recoverable the cost of transportation to the place where the victim had been told that her husband lay injured. He said merely this: "[a]s to this $1 \mathrm{~s}, 10^{1 / 2 \mathrm{~d} \text {, }}$ expended in railway fares on the faith of the defendant's statement, I think the case is clearly within the decision in Pasley $v$ Freeman. The statement was a misrepresentation intended to be acted on to the damage of the plaintiff'. ${ }^{77}$ Notice the complete absence of any insistence that the election to send friends to the site of the supposed accident must fall within some or other category of recognised or protected choices. Instead, Wright J. required no more than that the representation should have been "acted on". If all that need be shown is that the claimant has in some way detrimentally "acted on" the defendant's

\footnotetext{
${ }^{76}$ Logical limits are one thing, while specifically stipulated limits are another. So, e.g., it has been suggested that in Australia deceit is specifically excluded from the matrimonial setting by virtue of the Family Law Act 1975 (Cth.), see Magill v Magill [2006] H.C.A. 51, at [87] per Gummow, Kirby and Crennan JJ. It is clear, however, that no such exception exists in the matrimonial setting in either England or Canada: see Beyers v Green [1936] 1 All E.R. 613 and Graham v Saville [1945] 2 D.L.R. 489, respectively.

${ }^{77}$ [1897] 2 Q.B. 57, 58 (emphasis added).
} 
false claim, then it is hard to see what grounds the claim that deceit is enlivened only where "certain types of choices" have been made by the claimant.

In summary, then, the tort of deceit can be viewed as being available when the claimant's decision-making autonomy is interfered with so as to cause her to act in such a way that a recognised form of harm is suffered as a consequence of acting in that way. Accordingly, although we ought sensibly to dismiss as too vague Goldberg, Sebok and Zipursky's original formulation, we can nonetheless distil from it the following, more precise one:

The gist of deceit is an interference with the victim's decision-making autonomy that occurs by virtue of one of the established types of misinformation (laid down in Derry $v$ Peek) and which results in a recognized form of harm.

If this formulation is correct, then all that remains to be unearthed is the type (or types) of harm covered by this tort.

As noted earlier, there are many torts scholars who consider deceit to be a purely economic tort. This is certainly the way that it is normally portrayed. Presumably, this is because it is typical for it to be invoked in connection with economic losses. However, yet again, initial appearances prove to be deceptive. For it is a mistake to contend - as does Dobbs ${ }^{78}$ and the occasional judge ${ }^{79}-$ that this tort is exclusively concerned with protection of economic interests and that it ought to be regarded as a thoroughbred economic tort. ${ }^{80}$ This is because in just the same way that the tort of negligence makes available a remedy to those who suffer physical harm by virtue of their reliance on another's misrepresentation, ${ }^{81}$ so too, on existing authority, does the tort of deceit cover such injuries. ${ }^{82}$ It also responds to the suffering of mental distress, ${ }^{83}$ and even mere discomfort. ${ }^{84}$ Indeed, one might even consider the tort to be of perversely narrow scope if it did not protect such interests given that bodily and mental integrity are generally thought more worthy of protection by tort law

${ }^{78}$ In Dobbs' view, it is "a stand-alone economic or commercial tort that causes financial harm without causing physical harm either to person or to property": D.B. Dobbs, The Law of Torts (Minn. 2000), 1344.

${ }^{79}$ E.g. in Dura Pharmaceuticals, Inc. v Broudo 544 US 336, 343 (2005) the court stated that "the common law has long insisted that a plaintiff ... [must show] that he suffered actual economic loss".

${ }^{80}$ Many other leading textbooks on tort law also run the risk of creating the impression that deceit is an economic tort: C. Witting (Street on Torts (Oxford 2015), ch. 14), McBride and Bagshaw (op. cit., note 48, ch. 24) and S. Deakin et al (Tort Law (Oxford 2012) ch. 5) all present the tort of deceit under either the heading "economic torts" or "protection of economic interests".

${ }^{81}$ See, e.g. Perrett v Collins [1998] 2 Lloyd's Rep. 255; Prescott v Lancashire United Transport Co. Ltd. [1953] 1 W.L.R. 232.

82 Allan v Ellis \& Co [1990] 11 E.G. 78.

83 Shelley v Paddock [1980] Q.B. 348.

${ }^{84}$ Mafo v Adams [1970] 1 Q.B. 548. 
than purely economic interests. To put the matter otherwise, bodily and metal integrity occupy noncontroversially a more elevated position within the hierarchy of protected interests in tort law.

The better view, then, is that deceit, just like the tort of intimidation, is grossly mischaracterized when it is portrayed as a purely economic tort. Both intimidation and deceit have at their heart the decision-making autonomy of the claimant; and both are equally capable of being invoked to make good a range of different types of loss that are consequential upon a wrongful interference with this autonomy. The critical difference between the two torts is simply this. In the case of intimidation, it is the fact that the claimant has been coerced into making harmful decisions that he otherwise would not have made that is the animating force ${ }^{85}$ In the case of deceit, it is the fact that the claimant has been duped into making such decisions that is critical.

The importance of exposing what genuinely constitutes the gist and province of deceit is also (perhaps primarily) important at a theoretical level. ${ }^{86}$ Recognising that deceit is a rights-based tort which has nothing especially to do with the protection of economic interests is apt to prove useful in two separate ways. The first of these relates to the task of rationalizing the economic torts. As Robert Stevens has correctly observed, “the traditional grouping together of the 'economic torts' ... confuses ... [since] they have no inherent unity". ${ }^{87}$ Indeed, in terms of identifying any such unity, they are (in the words of Lord Wedderburn), "still awaiting their Atkin". ${ }^{88}$ Without suggesting that the simple removal of deceit from the hodgepodge of economic torts would be a panacea in this respect, it must at least be true that so doing is likely to simplify the task of identifying a unifying rationale. The task of supplying a unifying theory will inevitably be rendered easier if there is less to unify. Add to this the fact that intimidation, too, can be removed from the equation (since, like deceit, its gist is the right to decision-making autonomy rather than the infliction of economic loss), and the task of theorizing the economic torts appears far less daunting. Indeed, without the need to account for deceit and intimidation we can go a long way towards avoiding the unpalatable conclusion, marshalled in some quarters, ${ }^{89}$ that the economic torts may have a different rationale in a

\footnotetext{
85 See Murphy, op. cit., note 20.

86 Although, leading textbooks generally package deceit alongside other, specifically economic torts, none of them make Dobbs' mistake of suggesting that the tort can only be invoked in connection with the protection of commercial interests. They all at some point acknowledge - though typically in the footnotes - that deceit is also capable of providing a remedy in respect of non-economic, consequential losses.

${ }^{87}$ Stevens, op. cit., note 11, p. 297. Carty, also, has engaged with the absence of any clear, unifying rationale behind the economic torts: see H. Carty, "The Modern Functions of the Economic Torts: Reviewing the English, Canadian, Australian and New Zealand Positions" [2015] C.L.J. 261.

${ }^{88}$ Lord Wedderburn, "Rocking the Torts" (1983) 46 M.L.R. 224, 229.

${ }^{89}$ See, e.g. Carty, op. cit., note 87.
} 
two-party setting than they do in a three-party setting. ${ }^{90}$ Furthermore, the fact that we can legitimately remove intimidation and deceit from the frame certainly helps to highlight the anomalous nature of the remaining two-party economic torts: namely, lawful means and unlawful means conspiracy. ${ }^{91}$

The second theoretical implication of unearthing the true gist of deceit plays out in the context of the contemporary theoretical debate about whether torts are best understood within a rights-based or loss-based framework. For rights theorists, identifying damage as the gist of deceit is problematic because so doing tends to chime with the loss-based account of tort law from which they so strenuously seek to distance themselves. However, identifying the gist of deceit as the claimant's right to decision-making autonomy allows this tort (along with most other torts) to fall comfortably within the explanatory power of their preferred theoretical approach. On a rights-based understanding of deceit, such as the one offered here, the infringement of the claimant's right to decision-making autonomy is key; and the need to prove consequential loss is very much a secondary aspect of the tort. Put more accurately, the need to show consequential loss is a mere condition of actionability, but not an element of the tort strictu sensu. And some support for this view can be drawn from the dictum of Stephenson L.J. in Diamond $v$ The Bank of London and Montreal where he said: "[i]n deceit ... the false representation ... has to cause damage to be actionable, but no damage to the plaintiff is necessary for the tort to be committed". ${ }^{92}$

\section{MITIGATION AND CONTRIBUTORY NEGLIGENCE}

Attention now turns to a final problematic feature of deceit that has seemingly gone unnoticed: the fact that the mitigation rule applies to this tort, while the operation of the contributory negligence defence is excluded.

That the mitigation rule applies in this context stands on firm authority. In Smith $v$ New Court Securities Ltd. $v$ Citibank N.A., Lord Browne-Wilkinson was insistent that "the plaintiff must take all reasonable steps to mitigate his loss once he has discovered the fraud", while Lord Steyn said that "[t]he plaintiff is not entitled to damages in respect of loss which he could reasonably have

\footnotetext{
${ }^{90}$ Like deceit, intimidation is (these days at least) a purely two-party tort. If $D$ intimidates $T$ so as to cause loss to $C, C$ s action must now be framed in terms of the unlawful means tort: OBG v Allan [2008] UKHL 19; [2008] 1 A.C. 1, at [6][7] and [47] per Lord Hoffmann.

${ }^{91}$ As to the reasons why these two torts may fairly be considered anomalous, despite both standing on House of Lords authority, see note 20 above. And on the tension between them and the OBG $v$ Allan tort, see Carty, op. cit., note 87. 92 [1979] Q.B. 333, at 349.
} 
avoided". ${ }^{93}$ Accordingly, where a claimant is deceived by false bills of lading into accepting a substandard cargo, he ought nevertheless to take reasonable steps to sell that cargo at the best price obtainable rather than dispose of it at far less than market value. ${ }^{94}$ Ostensibly, then, there is nothing remarkable about the mitigation principle applying to the tort of deceit. It applies to all torts. ${ }^{95}$

It is equally clear that the defence of contributory negligence is unavailable in deceit cases. ${ }^{96}$ This fact gives cause for concern and deeper reflection in view of the common rationale behind the contributory negligence and mitigation principles. Why is the operation of only one of these principles excluded when both serve to reduce the quantum of damages payable in light of the claimant having acted with an objectively unreasonable lack of self-regard? How can the law adopt this contradictory approach, assuming it is right to assert, as do many jurists, that the only material difference between the mitigation rule and the defence of contributory negligence is a temporal one? Contributory negligence, they maintain, amounts to an unreasonable lack of self-regard prior to or contemporaneously with the commission of a tort, whereas the failure to mitigate involves an equivalent lack of self-regard after the commission of a tort. ${ }^{97}$ )

One must surely be forgiven for wondering why, if there are good reasons to disregard the claimant's pre-tort, foolhardy conduct and exclude the contributory negligence defence, there are not equally good - indeed, identical - reasons for excluding the operation of the mitigation rule in relation to post-tort conduct on the claimant's part. The other possibility, of course, is that there exists ultimately no good (i.e., principled) reason for excluding the contributory negligence defence, in which case there is probably also nothing theoretically objectionable about applying the mitigation rule to this tort. ${ }^{98}$ One way or another, it is certainly curious that this matter has never previously been thought to be odd, or received any serious juristic attention. In line with stated ambition of the

\footnotetext{
93 [1997] A.C. 254.

94 Standard Chartered Bank v Pakistan National Shipping Corp. \&o Others (Assessment of Damages) [2001] EWCA Civ 55; [2001] 1 All E.R. (Comm) 822, at [39] per Potter L.J.

95 The Liverpool (No 2) [1963] P. 64, 77-78.

96 Alliance \& Leicester Building Society v Edgestop Ltd. [1993] 1 W.L.R. 1462; Standard Chartered Bank v Pakistan National Shipping Corp. (No. 2) [2002] UKHL 43; [2003] 1 A.C. 959.

${ }^{97}$ See, e.g. P. Cane, Atiyah's Accidents Compensation and the Law (Cambridge 2006), 53, note 40; J. Goudkamp, "Rethinking Contributory Negligence" in E. Chamberlain et al, (eds.), Challenging Orthodoxy in Tort Law (Oxford 2013).

${ }^{98}$ In making this claim I do not mean to suggest that the only difference between contributory negligence and the mitigation rule is a temporal one. For example, as Goudkamp (loc. cit., p. 332) has observed, contributory negligence involves division of total loss whereas the mitigation rule involves subtraction of certain additional losses from the overall loss. Also, whereas acts of contributory negligence can only ever reduce the amount to which $C$ is entitled by way of damages, acts of mitigation that cost $C$ money can sometimes add to the recoverable loss in respect of which $C$ claims: see, D. Nolan, "Preventive Damages" (2016) 132 L.Q.R. 68, 71. Importantly, however, neither of these differences undermines the present point, which is simply that the rationale for both rules is identical: an objectively unreasonable lack of self-regard on the part of $C$ which augments his losses ought for that reason to be borne by $C$.
} 
present article - namely, to explore and explain the oddities we find in the tort of deceit - we need now to examine this inconsistent treatment of the mitigation and contributory negligence principles.

The mitigation rule, as noted already, is one of general application in tort law. Accordingly, the fact that it operates in the context of deceit gives no cause for the immediate raising of eyebrows. Rather, it is the exclusion of contributory negligence that seems to stand in need of explanation. On the face of it, a fairly simple explanation for this exclusion can be furnished. It is this. In the days when contributory negligence was still a complete defence, it was, as a matter of common law, excluded from the province of deceit. The Law Reform (Contributory Negligence) Act 1945 - a much maligned statute ${ }^{99}$ - merely perpetuates that position.

Under section 1 of the 1945 Act, the statute's apportionment provisions are enlivened only upon proof of "fault" on the part of the claimant. Section 4 of the Act defines "fault" in terms of "negligence, breach of statutory duty or other act or omission which ... would, apart from this Act, give rise to the defence of contributory negligence". Accordingly, conduct by a claimant cannot constitute "fault" within the meaning of the 1945 Act unless it was conduct of a kind that would have given rise to a defence of contributory negligence in the days before the statute was enacted. But since foolhardy acts by a claimant did not historically give rise to a defence of contributory negligence in deceit cases, they cannot now be treated as falling within the Act's concept of "fault". Put more succinctly: contributory negligence was not a defence to deceit prior to 1945, and its exclusion from that tort was continued by the wording of the 1945 Act. This is unsurprising since the 1945 Act was only ever intended to change the effect, but not the province, of the contributory negligence defence, as Aikens L.J. has confirmed in a recent case concerning battery. ${ }^{100}$

Unfortunately, however, unpicking the statute in this way does not furnish an entirely satisfactory answer to the questions with which this section began. The statute merely tells us that the defence is excluded from the province of deceit; but it does not (except in crude, definitional terms) explain why it is excluded. It says nothing about why, historically, the common law took the position that it did. This therefore still leaves open the possibility that the mitigation rule is out of place in deceit cases. Indeed, for this to be the case, all that would be required is for there to have been some sound historical reason(s) for excluding contributory negligence that can still be applied in the modern era, and with equal force, to its close relation, the mitigation rule. What, then, were

\footnotetext{
99 The Act is often criticised on the basis that it does not specify precisely how apportionment must be undertaken, and because it fails to define the pivotal concept of contributory negligence. But for a more fundamental attack see R. Stevens, "Should Contributory Fault be Analogue or Digital?" in A. Dyson et al (eds.), Defences in Tort (Oxford 2015). 100 Co-opertaive Group (CWS) Ltd. v Pritchard [2011] EWCA Civ 329; [2012] Q.B. 320, at [29]-[32].
} 
the historical reasons for excluding contributory negligence from deceit; and can any of those reasons be transferred to the mitigation rule today?

Prior to the introduction of the apportionment legislation, the main reason for making the contributory negligence defence unavailable in the context of the intentional torts was the fact that it was a complete defence. It was considered inappropriate that anyone who committed a deliberate wrong should be able to escape liability altogether simply on the basis that the claimant had acted with some relatively minor lack of self-regard and thereby contributed to the harm that he suffered. This justification, however, could never be applied to the mitigation rule - then or since - because the mitigation rule does not, and cannot, serve completely to exonerate the tortfeasor. ${ }^{101}$

The potential injustice associated with the fact that contributory negligence was historically an absolute defence was not, however, the only reason for its non-availability in the context of the intentional torts. There were, at least according to one eminent scholar, various other reasons for its exclusion. These also require examination.

Many years ago, Glanville Williams purported to have unearthed four such reasons. ${ }^{102}$ Admittedly, Williams had set himself the specific task of explaining the exclusion of contributory negligence from the torts of assault and battery. However, since each of the reasons that he gave was bound up with the fact that assault and battery are torts of intent, it might reasonably be supposed that Williams would have considered those reasons to have similar purchase in relation to deceit.

Williams' first reason, which in fact has been judicially invoked in the context of deceit, is that "intention to injure the plaintiff negatives all excuses", 103 thus rendering a defence of contributory negligence unavailable. The idea in play here is simply that the defendant cannot be heard to excuse himself where he has committed an intentional tort. However, as James Goudkamp has correctly observed, this supposed reason for excluding contributory negligence in the context of the intentional torts fails for the simple reason that contributory negligence is not an excuse: "excuses are defences that are concerned with the defendant" whereas "[c]ontributory negligence focuses on the claimant". ${ }^{104}$ So, even if it were true that intentional wrongdoing negates any would-be excuses, this would still not explain or necessitate the exclusion of contributory negligence from the tort of deceit. Equally, and more pertinently for present purposes, no such line of argument can be applied

\footnotetext{
${ }^{101}$ If the whole of $C$ s loss is attributable to $C$ s foolhardy, post-tort conduct, $C$ s conduct is appropriately characterised as a novus actus interveniens rather than as a failure to mitigate loss: see, e.g. McKew v Holland and Hannen and Cubitts (Scotland) Ltd. [1969] 3 All E.R. 1621.

${ }_{102}$ G. Williams, Joint Torts and Contributory Negligence (London 1951), 198.

103 Alliance \& Leicester Building Society v Edgestop Ltd. [1993] 1 W.L.R. 1462, at 1474 per Mummery J.

${ }^{104}$ J. Goudkamp, "Contributory Negligence and Trespass to the Person” (2011) 127 L.Q.R. 519, 520.
} 
to the mitigation rule. This, too, involves no attempt to invoke an excuse on the part of the tortfeasor.

Williams' second and third arguments against a the availability of the contributory negligence defence in the context of the intentional torts are that its exclusion both (1) helps to ensure that the law's punishment of the defendant is more effective than it would be if the defence were available, and (2) contributes to the deterrent effect of the law. However, both of these arguments also fail. ${ }^{105}$ To begin with, they are premised upon the highly contentious assumption that it is quite proper for tort law to punish and deter even though these are usually roles associated with the criminal law. Then there is the added problem that there can be no guarantee that the claimant's loss will be sufficiently large that the measure of damages will be considered punitive (or a deterrent) by the defendant. If the claimant's loss is modest, all that a successful invocation of contributory negligence can do is reduce the size of an already non-punitive, and relatively inconsequential, award. Furthermore, Williams' second and third arguments cannot be saved by pointing out that, even if the claimant's losses are modest, there is still the prospect of effective punishment/deterrence via an award of exemplary damages. This is because exemplary damages are not generally available in tort law: they may only be awarded within fairly strict limits laid down in Rookes v Barnard. ${ }^{106}$ Accordingly, there is no general prospect of punishment and deterrence being augmented via an award of exemplary damages.

Williams' third argument - that the goal of deterrence would be undermined if contributory negligence were made available in the context of the intentional torts - seems wrongheaded on one further score. This is that it is fanciful to suppose that the exclusion of contributory negligence makes any appreciable difference to the way in which those commit intentional torts will behave. Is it even remotely likely that those who decide to commit intentional torts do so with one eye on the prospect of the claimant acting in such a way as to contribute to their loss and thereby reduce the remedial burden that will ultimately be shouldered by the defendant? And even if this were not highly unlikely - which of course it is - what reason would we have to think that defendants are generally able to predict when claimants will act in this way, or, for that matter, knowledgeable about the content and mechanics of the contributory negligence defence?

\footnotetext{
${ }^{105}$ For a comprehensive destruction of Williams' reasoning in these respects, see Goudkamp, loc. cit., pp. 520-521. Only Goudkamp's most devastating arguments are invoked here and applied to the tort of deceit.

106 [1964] A.C. 1129. The exemplary damages riposte is further undermined, in the modern era, by the fact that the 1945 Act has no purchase with respect to exemplary damages: it applies only to the parties' respective shares in the "responsibility for the damage". And since the damage suffered can only ever be cashed out in terms compensatory, not punitive, damages, it follows that 1945 Act cannot be applied to exemplary damages.
} 
In sum, Williams' second and third putative arguments in favour of the exclusion of contributory negligence are wholly unpersuasive. Nor do they become any more persuasive - and for exactly comparable reasons - when applied to the mitigation principle. The absence of a mitigation rule would afford no guarantee that damages would serve a punitive function in any given case; and most defendants are as ignorant of tort law's mitigation rule, as they are of its contributory negligence defence.

Williams' fourth putative explanation of the non-availability of contributory negligence in relation to the intentional torts rests upon the idea that the "wrongful intention" of the defendant "outweighs the plaintiffs wrongful negligence so as to efface it altogether". ${ }^{107}$ Yet again, however, the argument fails. It presupposes greater moral blameworthiness on the part of the defendant in all cases. But such a presupposition is unwarranted because contributory negligence need not involve mere carelessness as to one's own interests or well-being. It may well take the form of acts that are just as morally tainted as those of the defendant, such as taking of one's own life. ${ }^{108}$ Accordingly, there can be no guarantee within the intentional tort setting that the moral stain upon the defendant's conduct will necessarily outweigh the moral stain upon the claimant's. ${ }^{109}$ This is especially true in the case of deceit. For deceit cases do not invariably involve something so morally reprehensible as the defendant treating the claimant's rights with outright contempt, or the defendant behaving as though the claimant were not worthy of the relevant rights. ${ }^{110}$ It is enough for the claimant to show that the defendant uttered the particular, untruthful statement "recklessly, careless whether it be true or false". ${ }^{111}$ There is no good reason to think, then, that recklessness on the part of the defendant should inevitably efface the lack of self-regard exhibited by the claimant given that the latter's lack of self-regard might well take the form of recklessness or even deliberate self-harm. ${ }^{112}$

If we attempt to apply this fourth argument to the mitigation rule we reach the same conclusion. This is because recklessness or a deliberate lack of self-regard on the part of the

\footnotetext{
107 Williams, op. cit., note 102, p. 198. This argument is obviously similar to, yet subtly different from, the historically grounded argument about $D$ not being entitled to a defence where $D$ acted deliberately and $C$ had only negligently contributed to his own loss. In that context, however, the principal objection was anchored to $D$ having a complete defence.

108 Corr v IBC Vehicles Ltd. [2008] UKHL 13; [2008] 1 A.C. 884.

109 See Goudkamp, op. cit., note 104, 521.

110 This is the Hegelian view of deceit, supported by Allan Beever in his "The Structure of Aggravated and Exemplary Damages" (2003) 23 O.J.L.S. 87, 89.

111 Derry v Peek (1889) 14 App. Cas. 337, 376 per Lord Herschell.

112 Authorities to this effect include Pilmoore v Hood (1838) Bing. N.C. 97; Redgrave v Hurd (1881) 20 Ch. D. 1; Dobell v Stevens (1825) 3 B. \& C. 623. In one Australian case, it was even held that $C$ was entitled to sue despite knowing that $D$ 's statement was not entirely true: see Gipps v Gipps [1978] 1 N.S.W.L.R. 454.
} 
claimant after the commission of the tort ought not necessarily to be considered less morally blameworthy than the defendant's wrongdoing. In short, William's fourth reason for the exclusion of contributory negligence from the intentional torts cannot plausibly be transferred to the mitigation rule in order to justify its exclusion from the tort of deceit.

Although none of Williams' reasons for excluding contributory negligence from the intentional torts can successfully be rolled out in relation to the mitigation rule, there does remain one further possible argument to consider. This argument - originally suggested in the arena of negligent (not fraudulent) misrepresentations ${ }^{113}$ - is as follows. Where the defendant has induced the claimant's detrimental reliance, it is untenable for the defendant to argue that he does not have to bear full responsibility for the claimant's loss because this loss was, in part, attributable to the claimant being unreasonably gullible, and unreasonably foolish in relying on the false statement that was made. The problem with this line of argument is that it is internally contradicted. It involves the defendant trying to have it both ways. On the one hand he is admitting that the claimant acted in the way that she did because he induced her to do so. ${ }^{114}$ Yet on the other hand he is seeking to assert that the claimant acted in the way that she did because she was unreasonably gullible. In order to prevent such a contradictory defence, the law excludes altogether contributory negligence from the sphere of deceit. By so doing, it forecloses the prospect of the defendant seeking to reduce the damages payable by reference to the fact that the claimant was foolish to rely on the false statement made.

So far as it goes, this train of thought does indeed furnish a plausible explanation of why the defendant may not rely on contributory negligence in the context of deceit. The law obviously shies away from granting a defence to anyone who seeks to base their defence on two contradictory claims. There are, however, limits to how far this train of thought can take us. In particular, the argument only has traction in relation to foolhardy acts on the part of the claimant that were specifically induced by D's false statement. Other foolhardy acts on her part are not caught by it. They therefore remain candidates for the application of the contributory negligence defence so long as those acts serve to contribute to the overall harm suffered. An example may help to explain the point.

Suppose that $A$, who has taken powerful, concentration-affecting drugs, induces $B$ to accept a lift in his car by persuading $B$ that he is fit to drive when he knows very well that he is not. Suppose

\footnotetext{
113 See Gran Gelato Ltd. v Richclif (Group) Ltd. [1992] Ch. 560, 574 per Sir Donald Nicholls V.-C.

114 Were this not so, $D$ would have no need of a defence.
} 
also that, believing this, $B$ accepts a lift with $A$. And, finally, assume that $B$ chooses, for idiotic personal reasons, not to wear her seatbelt. In such circumstances, we can identify the election not to wear a seatbelt as an act on the part of $B$ that was not specifically induced by $A$, but which nonetheless contributed to the harm that she suffered. Why, in such circumstances, should $A$ be precluded from adverting to $B$ 's stupid election to forego the use a seatbelt when the quantum of damages is being assessed? There would be no contradiction here between what the defendant was prepared to admit (that he induced $B$ to accept a lift), and what he was seeking to rely upon by way of a defence (the fact that $B$ had quite independently of any inducement made the idiotic choice not to wear a seatbelt). ${ }^{115}$

Not only does the final argument against the availability of contributory negligence in the context of deceit have no traction in a case such as this, it also has no traction in the context of the mitigation principle. Its bite is confined to foolhardy acts that were specifically induced by the defendant. By definition, then, it has no application whatsoever to careless post-tort behaviour on the part of a claimant which serves to augment the harm suffered. Accordingly, this argument is not even partially effective in the context of the mitigation rule. That rule never encounters acts or choices that have been specifically induced by the defendant.

The conclusion we inevitably reach is this. Only the much-criticised language of the 1945 Act explains the exclusion of contributory negligence from the tort of deceit. ${ }^{116}$ The Act merely perpetuates the old common law rule. But the old common law rule has nothing theoretically satisfying to ground it in the modern era. It is the absence of any such sound theoretical basis for the exclusion of contributory negligence that serves to allay the worry that the mitigation rule might also be out of place in relation to this tort. In the end, our abiding thought is more likely to be that, nowadays, there is no defensible reason to exclude either contributory negligence or the mitigation principle from the tort of deceit. With the introduction of the apportionment legislation, there disappeared the only theoretically respectable reason for excluding contributory negligence from this tort: the fact that contributory negligence was historically a complete defence. And it is certainly

\footnotetext{
115 If the hypothetical in the text is thought rather fanciful, it is noteworthy that one need only modify slightly the facts of Schneider $v$ Heath (1813) 3 Camp. 506 in order to see another such example. In that case, $D$ floated a ship in order to conceal faults that existed below the waterline. If $C$ bought the ship, ignorant of the defects, and then (although not obliged or induced to do so) foolishly put the ship to commercial use without checking its seaworthiness with the result that the ship sank, there would presumably be a good case for arguing that $C$ s contributory negligence caused the additional loss.

116 In Standard Chartered Bank v Pakistan National Shipping Corp. (No. 2) [2002] UKHL 43; [2003] 1 A.C. 959, the House of Lords specifically confirmed the reason given in the text for the non-applicability of the 1945 Act to deceit cases.
} 
noteworthy that there have been a number of decisions in the USA in which the comparative fault doctrine has been applied quite satisfactorily to intentional torts in the modern age. ${ }^{117}$

\section{CONCLUSION}

In this study, I have tried to expose and unravel a paradox associated with the tort of deceit. It is that certain of its key elements - which appear on the surface to be entirely quotidian - turn out to be the hardest to explain, while other key facets, which superficially give the impression of abnormality, are what in fact render this tort much less peculiar than it initially seems.

I began by exploring the precise role of, and justification for, the reliance requirement in deceit. This exploration was important in its own right; but it also shone light on another matter. It allowed us to understand the relationship (and distinctions between) between deceit, on the one hand, and the tort of causing loss by unlawful means, on the other. A clear grasp of this relationship in turn revealed what some would consider a gap in the web of common law protection. The exposure of this gap placed centre stage the question of whether the reliance component in deceit can be justified. Upon reflection, it was concluded that by far the stronger theoretical case can be made in favour of retaining the reliance requirement ${ }^{118}$ even though it stands out, initially, as an unusual test of causation in tort law.

A second aim of this article was to tackle the impression - created by the courts repeatedly emphasising the need to show harm - that deceit is a loss-based tort. Once again, deeper reflection revealed that first impressions can be misleading and that a better understanding is that the gist of this tort is the right to decision-making autonomy. Identifying its gist in this way was significant for two main reasons. First, it allowed us to see why it is a mistake - conspicuously made by certain jurists and judges - to characterise deceit as a purely an economic tort. Secondly, it allowed us to assess whether deceit fits within, or tends to confound, rights-based theories of tort law that are these days very much in vogue. For leading rights theorists who have considered the matter, deceit has thus far proved a tricky tort to explain. On this side of the Atlantic, Robert Stevens has been able to do no better than essentially assert that deceit is a rights-based tort in which the critical right is the simple, putative right not to be lied to. On Stevens' reckoning, the tort also requires - for

\footnotetext{
${ }^{117}$ For details of these cases, and for a set of pragmatic arguments about how best the doctrine should be confined in its extension to the intentional torts, see W.J. McNicholls, "Should Comparative Responsibility Ever Apply to Intentional Torts?” (1984) 37 Oklahoma L. Rev. 641, 644-5.

118 The need to show reliance, recall, ensures that deceit conforms to the structural norm of tort law. Abandoning the reliance component would therefore come at high cost in terms of tort law's coherence. I doubt whether this is a cost worth paying in order to plug a small, remedial gap in the common law.
} 
reasons that he cannot (or at least does not) supply - proof of consequential loss. On the other side of the Atlantic, Goldberg, Sebok and Zipursky have done only a little better. Unlike Stevens, their depiction of the tort does not clash with existing authority; but it only manages this feat by being incredibly vague. Recall: for these theorists, deceit protects the victim's "interest in making certain kinds of choices" in "certain settings" free from "certain forms of misinformation". They offer no elaboration of what the relevant "kinds of choices", "settings" and "forms of misinformation" might be, however. On my account, a much more robust explanation of the rights basis and province of this tort could be unearthed.

The main matter tackled in this article concerned the theoretically unsatisfying way in which deceit's remedial province is qualified. The usual mitigation principle applies, while the contributory negligence defence does not even though both principles are rooted in the self-same concern: to take into account, when computing damages payable, an unreasonable lack of self-regard on the part of the claimant. The simple explanation for this peculiarity - the fact that 1945 Act continues the old common law approach of excluding the contributory negligence defence from cases of deceit - is not, however, by itself good enough. It leaves us wondering not only why the common law historically adopted the stance that it did, but also whether the historical reasons for its exclusion might, even today, be applied to its close relation the mitigation rule. Under close examination, it turns out that there is no theoretically sound reason why the law should exclude either contributory negligence or the mitigation principle from the province of deceit. As such, we are able to conclude, first, that the mitigation rule has a perfectly legitimate role to play in this tort and, secondly, that although the exclusion of contributory negligence can be explained by reference to the wording of the 1945 statute, we ought not to confuse explanation with justification. Put otherwise, we saw that the effect of the 1945 statute cannot be justified as a matter of principle.

Ultimately, it is hoped that this study offers observations of both practical and theoretical significance. Practitioners ought to welcome a clearer understanding of deceit's true nature and province given that, as noted at the outset, this tort continues to be invoked in the courts on a fairly regular basis. Equally, so far as legal theory is concerned, an examination of deceit's peculiarities feeds directly into two important contemporary theoretical debates: about whether tort law is best explained according to a rights-based understanding; and about whether the economic torts are susceptible to rational theorization. It is hoped that some valuable light has been shed on these matters, too. 